\title{
Adventitious rooting of cultivars and clonal selections of Prunus spp. rootstock under intermittent mist system ${ }^{1}$
}

\author{
Newton Alex Mayer ${ }^{2 * \mathbb{D}}$, Jéssica Luz Lopes ${ }^{3}$, Bernardo Ueno ${ }^{2}$
}

$10.1590 / 0034-737 X 202168030009$

\begin{abstract}
To reduce peach tree losses due the Peach Tree Short Life (PTSL), the main research line in Brazil is to select tolerant rootstock and perpetuate it by cloning methods. The objective was to evaluate adventitious rooting capacity of softwood cuttings of three cultivars and several clonal rootstock selections of Prunus spp., under intermittent mist system. Two trials were conducted and 'Capdeboscq', 'Okinawa' (P. persica) and 'Sharpe' ['Chickasaw' (P. angustifolia Marsh.) x Prunus spp.] were used as reference cultivars. After 53 days (trial 1) and 72 days (trial 2) from the cutting setting, we conclude that softwood cuttings under intermittent mist system are a feasible way to propagate peach rootstock selections of 2010/2011 PTSL selection cycle. Root quality was satisfactory in most selections, with high percentages of cuttings suitable for transplanting and excellent root number and root length. OS-GRA-10-17, VEHGRA-10-31, VEH-GRA-10-32, VEH-GRA-10-37 and VEH-GRA-10-38 selections had the highest mortality and the lower percentages of live rooted cuttings. The ease of vegetative propagation must be taken into account in more promising rootstock.
\end{abstract}

Keywords: Rosaceae; softwood cutting; cloning; PTSL syndrome.

\section{INTRODUCTION}

Among main agronomic problems that affect peach in Rio Grande do Sul State, Brazil, there are the absence of clonal rootstocks adapted to the edaphoclimatic conditions of the state's peach area and which present tolerance to the Peach Tree Short Life (PTSL). This syndrome has affected commercial peach and plum orchards, especially in Pelotas area since late 1970s, which greatly reduces orchard life (Mayer et al., 2009; Mayer \& Ueno, 2012; Ueno et al., 2019; Mayer \& Ueno, 2021).

The syndrome is characterized by a collapse of peach tree scion at winter, with decreasing or standstill growth, weak and/or uneven sprouts, late or nonexistent flowering, and shoot death, parts or whole scion death, but the rootstock usually remains alive (Mayer et al., 2009; Mayer \& Ueno, 2012; Campos et al., 2014; Ueno et al., 2019; Alba et al., 2019). In Southeast of the United States
(South Carolina, North Carolina and Georgia), the Peach Tree Short Life (PTSL) manifests characteristics and symptoms very similar to those observed in South Brazil (Brittain \& Miller, 1978; Okie et al., 1994; Beckman et al., 2008; Beckman et al., 2012; Mayer \& Ueno, 2012; Campos et al., 2014; Ueno et al., 2019). With the technological advances obtained through of breeding programs for rootstocks, there was a significant reduction in tree losses caused by the PTSL syndrome in the United States, which culminated in the releasing of tolerant rootstock 'Guardian ${ }^{\circledR}$, 'Sharpe' and 'MP-29 ${ }^{\circledR}$ ' (Okie et al., 1994; Okie \& Nyczepir, 2004; Beckman et al., 2008; Beckman et al., 2012). 'Sharpe' is in the public domain and was introduced in Brazil by Embrapa Clima Temperado (Mayer \& Ueno, 2015).

In Brazil, the PTSL syndrome is restricted to the peach areas of Rio Grande do Sul (Mayer \& Ueno, 2012; Campos

\footnotetext{
Submitted on May $11^{\text {th }}, 2020$ and accepted on December 1 $11^{\text {th }}, 2020$.

Research financed by Empresa Brasileira de Pesquisa Agropecuária (Embrapa) and Conselho Nacional de Desenvolvimento Científico e Tecnológico (CNPq).

2 Embrapa Clima Temperado, BR 392, km 78, Pelotas, Rio Grande do Sul, Brazil. alex.mayer@embrapa.br; bernardo.ueno@embrapa.br

3 Instituto Federal de Educação, Ciência e Tecnologia Sul-riograndese, Campus Visconde da Graça, Pelotas, Rio Grande do Sul, Brazil. jessicalopesgestaoambiental @gmail.com

*Corresponding author: alex.mayer@embrapa.br
} 
et al., 2014; Ueno et al., 2019; Mayer \& Ueno, 2021). The rootstock used, in most of the peach and plum orchards in the State, are formed from seed germination and cause genetic variability, usually coming from canning industry (pits as residue of peach processing). This rootstock propagation method produces trees with genetically heterogeneous root systems, does not allow preservation of original rootstock's genetic identity, prevents varietal identification and manifests differences in vigor, yield, fruit quality, different reactions to biotic and abiotic factors and also to the PTSL syndrome (Mayer et al., 2009; Mayer \& Ueno, 2012; Mayer et al., 2014a; Menegatti et al., 2019; Mayer \& Ueno, 2021). If the genetic variability of rootstock is undesirable in commercial orchards, on the other hand it is essential in a rootstock selection at field with PTSL history (Mayer et al., 2009).

In view of this situation, researchers of the Embrapa Clima Temperado (Pelotas, Brazil) started a peach rootstock selection focusing in genotypes tolerant to the PTSL. After seven cycles of selection and cloning, 146 genotypes were rescued, which are maintaining in the "Prunus rootstock collection" (Mayer \& Ueno, 2021). Among the desirable characteristics of a good rootstock, in addition to scion graft compatibility and tolerance to biotic and/or abiotic soil problems, vegetative propagation is one of main selection criteria (Okie \& Nyczepir, 2004; Beckman et al., 2008; Reighard \& Loreti, 2008; Beckman et al., 2012; Warschefsky et al., 2016; Oliveira et al., 2018). Therefore, in order to advance in rootstock selection process, it is necessary to know the propagation potential of selected clones, comparing them with reference cultivars.

As many species within the genus Prunus are difficult to root (Anderson et al., 2016) and rooting of softwood cuttings is influenced by genetics (Hartmann et al., 2002; Neèas \& Krška, 2013; Mayer et al., 2014b; Mayer et al., 2015a; Anderson et al., 2016; Mayer et al., 2020), our hypothesis is that rootstock selections have a different potential for adventitious rooting of cuttings. The objective was to evaluate adventitious root potential in softwood cuttings from three cultivars and several clonal selections of Prunus spp. under intermittent mist system.

\section{MATERIALAND METHODS}

Mother trees of rootstock selections were originally selected in several commercial peach orchards in the Rio Grande do Sul (Brazil) that contained asymptomatic trees neighboring trees with typical PTSL symptoms in 2010 (Mayer et al., 2009). With the scion cut methodology below the grafting point carried out between July and September, new and exclusive shoots of each rootstock was stimulated, which were collected at beginning of the following year for cloning by softwood cuttings, completing the biannual selection and rescue cycle (Mayer et al., 2009). Each selected clone received a code, including initial letters of peach grower's name where the selection was made; peach scion cultivar; selection year; and clone number. Trees were established in "Prunus rootstock collection”, at Embrapa Clima Temperado (Pelotas, Rio Grande do Sul, Brazil) to constitute mother trees (Mayer \& Ueno, 2021).

Were used softwood shoots collected in 7-years-old mother trees from 30 clonal selections belongings 2010/ 2011 selection cycle. For operational and infrastructure reasons, two trials (named as 1 and 2) were carried out, each one containing 15 selections. Three cultivars were also used as reference: a) 'Capdeboscq' ( . persica), scion peach cultivar released for canning. Its seeds were also widely used as a rootstock until the 1980s, in Southern Brazil, due to ease of obtaining a reasonable seed germination and good adaptation to edaphoclimatic conditions (Mayer et al., 2014a); b) 'Okinawa' (P. persica), a rootstock cultivar most used in Southeast Brazil for stone fruit, being normally propagated by seeds obtained from mother trees (Mayer et al., 2014a); c) 'Sharpe' ['Chickasaw' (P. angustifolia Marsh.) x Prunus spp.], rootstock cultivar resistant to Meloidogyne incognita and M. floridensis; tolerant to Armillaria tabescens and PTSL. It is easily propagated by softwood or hardwood cuttings (Beckman et al., 2008; Mayer \& Ueno, 2015).

Between August $12^{\text {th }}$ and $14^{\text {th }}, 2018$, mother trees were drastically pruned, in order to stimulate vigorous vegetative growth (Figure 1a.). After 129 days of pruning, we proceeded to collect softwood shoots (Figure 1b.) for trial 1, transferring them quickly to intermittent mist system to avoid dehydration. Softwood cuttings were $12 \mathrm{~cm}$-long, with distal apical bevel and basal transversal cuts, diameter between 8 and $10 \mathrm{~mm}$, being left two or three distal nodes with all half-leaves to reduce transpiring rate (Figure 1c.). The cutting base was immersed in a hydroalcoholic solution at $50 \%$ (hydrated ethyl alcohol $96^{\circ} \mathrm{GL}+$ distilled water) of 4, 3 - indolylbutyric acid - IBA $\left(\mathrm{C}_{12} \mathrm{H}_{13} \mathrm{NO}_{2}\right.$, purity $>98 \%$, Vetec $^{\circledR}$ ) at 3,000mg.L $\mathrm{L}^{-1}$ by fast immersion of 5 seconds (Figure 1d.) (Hartmann et al., 2002; Mayer et al., 2018; Mayer et al., 2020). Trial 2 was set up on $13^{\text {th }}$ and $14^{\text {th }}$, January/ 2019, with same methodology adopted in trial 1.

Cuttings were placed in perforated plastic boxes $(46 \mathrm{x}$ $30 \times 10 \mathrm{~cm}$ ) containing a fine vermiculite and perlite mixture $(1: 1, \mathrm{v} / \mathrm{v})$. These containers were kept on $1 \mathrm{~m}$-high iron benches under intermittent misting system located inside an arch-type greenhouse ( 24 x 8m, with $3 \mathrm{~m}$ high), without air temperature nor air relative humidity control. Mist system was composed of a nozzle's line (Tietze ${ }^{\circledR}$ Violetatype, equidistant $1 \mathrm{~m}$ each other), placed at $70 \mathrm{~cm}$ above containers. A 50\% reflective screen (Lumineti ${ }^{\circledR}$ ) was placed $1.2 \mathrm{~m}$ above the mist system, to reduce sun radiation. 
Intermittent mist system was programmed by a timer to be activated for 10 seconds each 5 minutes, in the first 20 days of each trial, which allowed maintenance of constant moist on leaf surface (Ruter, 2015; Mayer et al., 2018; Mayer et al., 2020). In the following days, off-period was gradually increased at night until $45^{\text {th }}$ and, after that, completely turned-off at night.

Treatments consisted of 15 clonal rootstocks, selected as tolerant to the PTSL, besides three reference cultivars (total of 18 treatments each trial). The trials were setting according to a completely randomized design, with four replications of 10 cuttings per plot. Air temperature $\left({ }^{\circ} \mathrm{C}\right)$ and air relative humidity (\%) were recorded every $30 \mathrm{~min}$ with a Datalogger (AK172-V2, AKSO), kept in shade 70 $\mathrm{cm}$ above the misting nozzles line. Data were summarized in Table 1.

After 53 and 72 days of trial 1 and 2 setting, respectively, the following variables were evaluated: 1) percentage of cuttings with original leaves; 2) percentage of sprouted cuttings. Cuttings were carefully removed from the rooting substrate, immersed in water for cleaning, and were evaluated: 3 ) percentage of callus cutting; 4) percentage of dead cuttings; 5) percentage of dead rooted cuttings; 6) percentage of live rooted cuttings. Then, the live rooted cuttings were classified into: 7) percentage of rooted cuttings suitable for transplanting, that is, those with a minimum of four roots per cutting, distributed around the cutting base; 8) percentage of rooted cuttings unsuitable for transplanting, those with three or less roots, located unilaterally at the cutting base (Mayer et al., 2014b). Cuttings classified as live rooted, the following were also evaluated: 9) root number per cutting; 10) root length $(\mathrm{cm})$ of the three largest roots per cutting, using a ruler. Those variables expressed as percentage were transformed to arc $\sin \sqrt{x / 100}$, and remain variables have not been transformed. Data were subjected to ANOVA by F-test and means compared by Scott-Knott test (Canteri et al., 2001).

\section{RESULTS}

Data of callused cutting percentage were not presented, due to low values obtained. In trial 1 , of the fifteen selections tested, only four presented callus, with $5.00 \%$ (VHS-SEN-10-07 and OS-JAD-10-13) and 2.50\% (VHS-SEN-10-10, OS-GRA-10-20), in addition to 'Capdeboscq' and 'Sharpe' (2.50\%). In trial 2, callus were
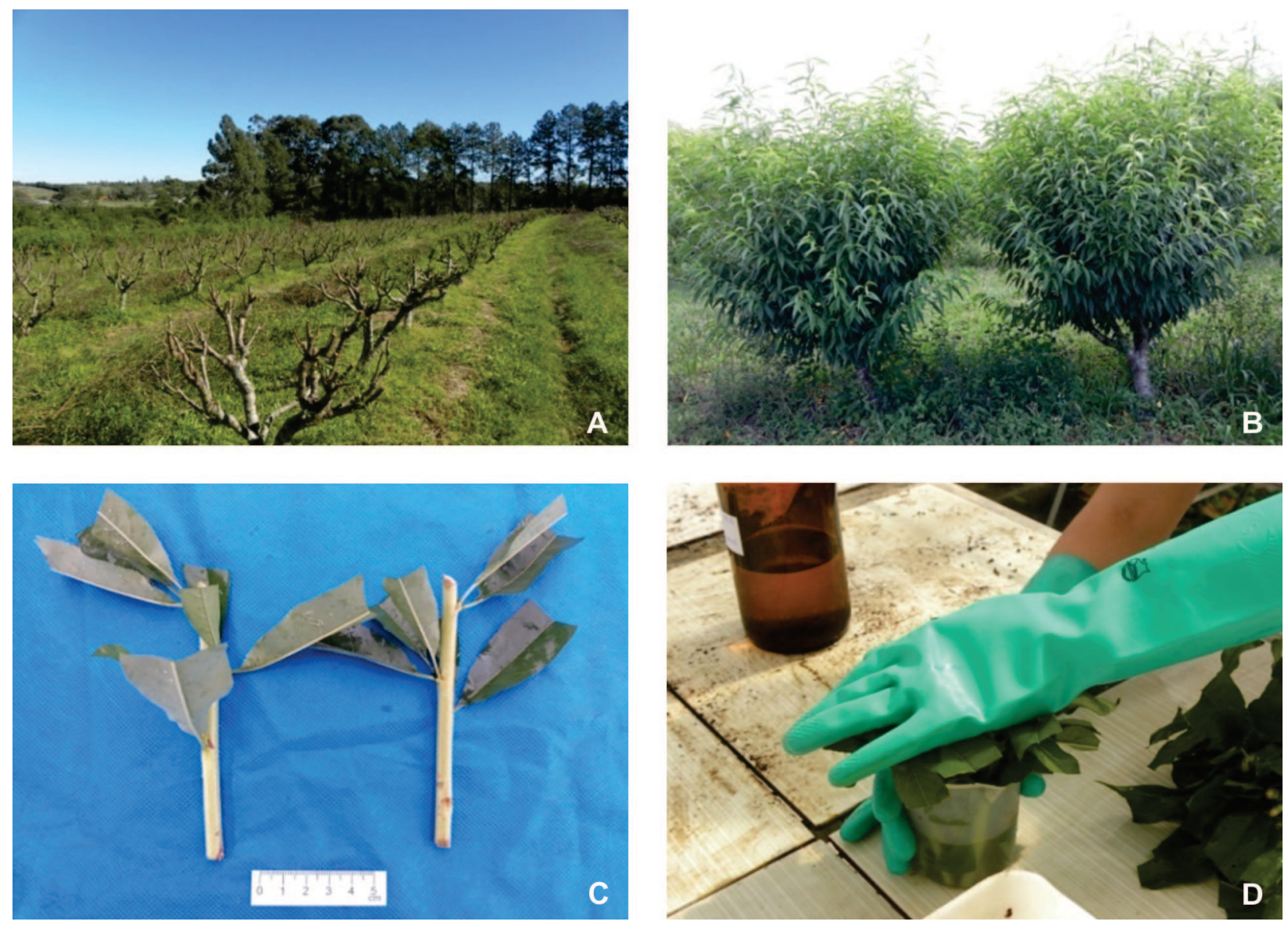

Figure 1: A) Mother trees of peach rootstock selections drastically pruned in August; B) adequate softwood shoots for cutting preparation; C) softwood cuttings ready for IBA treatment; D) IBA treatment by fast immersion. Photos: Newton Alex Mayer. 
observed only in JTV-GRA-10-46 (7.50\%), JTV-JAD-10-41 (5.00\%), VEH-GRA-10-39, JTV-GRA-10-47, ISD-GRA-1053, VS-ELD-10-59 and 'Capdeboscq' (2.50\%). Significant statistical differences were found in eight variables in trial 1 (Tables 2 and 3) and only three variables in trial 2 (Tables 4 and 5).

Three variables (percentages of dead cuttings, of dead rooted cuttings and of rooted cuttings unsuitable for transplanting) of the nine evaluated variables in each trial are undesirable, as they reduce propagation potential (yield) of a selection or cultivar. In trial 1, most selections (eight) had a high percentage of dead cuttings (between 35.00 and $52.50 \%$ ), as well as the most (eleven) had high percentages of dead rooted cuttings (between 15.0 and $32.5 \%$ ), so that total mortality (dead cuttings + dead rooted cuttings) reached $82.50 \%$ in two selections (VEH-GRA10-31 and VEH-GRA-10-32). The three reference cultivars are found in groups with the lowest percentages for these two variables, so that percentages of total mortality were low, with 2.50\% ('Capdeboscq'), 22.50\% ('Okinawa') and $17.50 \%$ ('Sharpe'). Among selections, as positive highlights, VHS-SEN-10-07 and VHS-SEN-10-10 had the

Table 1: Summary of environmental data recorded inside greenhouse during trial 1 (from Dec/07/2018 to Jan/28/2019) and trial 2 (from Jan/08/2019 to Mar/19/2019)

\begin{tabular}{lrr}
\hline Environmental data & Trial 1 & Trial 2 \\
\hline Maximum air temperature $\left({ }^{\circ} \mathrm{C}\right)$ & 44.8 & 43.9 \\
Minimum air temperature $\left({ }^{\circ} \mathrm{C}\right)$ & 9.9 & 12.2 \\
Air temperatures $>27.0^{\circ} \mathrm{C}(\%$ of total time) & 35.7 & 34.4 \\
Air temperatures $<15.0^{\circ} \mathrm{C}(\%$ of total time) & 1.9 & 1.1 \\
Maximum thermal amplitude per $24 \mathrm{~h}\left({ }^{\circ} \mathrm{C}\right)$ & 27.2 & 24.1 \\
Minimum thermal amplitude per $24 \mathrm{~h}\left({ }^{\circ} \mathrm{C}\right)$ & 4.5 & 7.0 \\
Maximum air relative humidity $(\%)$ & 100.0 & 100.0 \\
Minimum air relative humidity $(\%)$ & 24.7 & 27.1 \\
Maximum amplitude per $24 \mathrm{~h}$ of air relative humidity $(\%)$ & 75.3 & 72.9 \\
Minimum amplitude per $24 \mathrm{~h}$ of air relative humidity $(\%)$ & 0.0 & 0.0 \\
\hline
\end{tabular}

Table 2: Rooting response of softwood cuttings from cultivars and clonal selections of Prunus spp. rootstocks under intermittent mist system (trial 1)

\begin{tabular}{lccccc}
\hline Rootstock & $\begin{array}{c}\text { Dead } \\
\text { cuttings }\end{array}$ & $\begin{array}{c}\text { Dead rooted } \\
\text { cuttings }\end{array}$ & $\begin{array}{c}\text { Live rooted } \\
\text { cuttings }\end{array}$ & $\begin{array}{c}\text { Suitable } \\
\text { rooted cuttings }\end{array}$ & $\begin{array}{c}\text { Unsuitable } \\
\text { rooted cuttings }\end{array}$ \\
\cline { 2 - 5 } VHS-SEN-10-07 & & \multicolumn{1}{c}{$\boldsymbol{c})$} & & \\
VHS-SEN-10-08 & $5.00 \mathrm{~b}$ & $10.00 \mathrm{~b}$ & $77.50 \mathrm{a}$ & $44.38 \mathrm{a}$ & $55.63 \mathrm{~b}$ \\
VHS-SEN-10-09 & $35.00 \mathrm{a}$ & $27.50 \mathrm{a}$ & $37.50 \mathrm{~b}$ & $60.00 \mathrm{a}$ & $40.00 \mathrm{~b}$ \\
VHS-SEN-10-10 & $47.50 \mathrm{a}$ & $5.00 \mathrm{~b}$ & $47.50 \mathrm{~b}$ & $56.67 \mathrm{a}$ & $43.33 \mathrm{~b}$ \\
OS-JAD-10-12 & $17.50 \mathrm{~b}$ & $5.00 \mathrm{~b}$ & $77.00 \mathrm{a}$ & $47.92 \mathrm{a}$ & $52.08 \mathrm{~b}$ \\
OS-JAD-10-13 & $40.00 \mathrm{a}$ & $20.00 \mathrm{a}$ & $40.00 \mathrm{~b}$ & $34.38 \mathrm{a}$ & $40.63 \mathrm{~b}$ \\
OS-GRA-10-16 & $20.00 \mathrm{~b}$ & $25.00 \mathrm{a}$ & $50.00 \mathrm{~b}$ & $48.75 \mathrm{a}$ & $51.23 \mathrm{~b}$ \\
OS-GRA-10-17 & $12.50 \mathrm{~b}$ & $32.50 \mathrm{a}$ & $55.00 \mathrm{~b}$ & $62.38 \mathrm{a}$ & $37.62 \mathrm{~b}$ \\
OS-GRA-10-18 & $52.50 \mathrm{a}$ & $25.00 \mathrm{a}$ & $22.50 \mathrm{c}$ & $66.67 \mathrm{a}$ & $33.33 \mathrm{~b}$ \\
OS-GRA-10-20 & $47.50 \mathrm{a}$ & $5.00 \mathrm{~b}$ & $47.50 \mathrm{~b}$ & $7.14 \mathrm{a}$ & $92.86 \mathrm{a}$ \\
EM-PRE-10-21 & $35.00 \mathrm{a}$ & $32.50 \mathrm{a}$ & $30.00 \mathrm{c}$ & $77.50 \mathrm{a}$ & $22.50 \mathrm{~b}$ \\
EM-SEN-10-25 & $25.00 \mathrm{~b}$ & $20.00 \mathrm{a}$ & $55.00 \mathrm{~b}$ & $46.23 \mathrm{a}$ & $53.77 \mathrm{~b}$ \\
ENP-JAD-10-27 & $10.00 \mathrm{~b}$ & $15.00 \mathrm{a}$ & $75.00 \mathrm{a}$ & $53.18 \mathrm{a}$ & $46.83 \mathrm{~b}$ \\
VEH-GRA-10-31 & $22.50 \mathrm{~b}$ & $27.50 \mathrm{a}$ & $50.00 \mathrm{~b}$ & $49.11 \mathrm{a}$ & $50.89 \mathrm{~b}$ \\
VEH-GRA-10-32 & $50.00 \mathrm{a}$ & $32.50 \mathrm{a}$ & $17.50 \mathrm{c}$ & $35.00 \mathrm{a}$ & $40.00 \mathrm{~b}$ \\
Capdeboscq & $50.00 \mathrm{a}$ & $32.50 \mathrm{a}$ & $17.50 \mathrm{c}$ & $8.33 \mathrm{a}$ & $91.67 \mathrm{a}$ \\
Okinawa & $2.50 \mathrm{~b}$ & $0.00 \mathrm{~b}$ & $90.00 \mathrm{a}$ & $85.42 \mathrm{a}$ & $14.58 \mathrm{~b}$ \\
Sharpe & $17.50 \mathrm{~b}$ & $5.00 \mathrm{~b}$ & $77.50 \mathrm{a}$ & $81.25 \mathrm{a}$ & $18.75 \mathrm{~b}$ \\
\hline F & $12.50 \mathrm{~b}$ & $5.00 \mathrm{~b}$ & $80.00 \mathrm{a}$ & $69.45 \mathrm{a}$ & $30.56 \mathrm{~b}$ \\
\hline rotstock & $4.61 * *$ & $4.17 * *$ & $5.87 * *$ & $2.14 *$ & $2.07 *$ \\
\hline CV $(\%)$ & 42.34 & 55.42 & 27.15 & 52.56 & 57.67 \\
\hline
\end{tabular}

Means followed by different letters in the column differ from each other by the Scott-knott test. * Significant at 5\% error probability; ** significant at $1 \%$ error probability. 
lowest percentages of total mortality $(15.0 \%$ and $22.5 \%$, respectively), which were also found in the group with lower percentages of rooted cuttings unsuitable to transplant. In trial 2, there were no statistically significant differences between treatments for percentages of dead cuttings and for dead rooted cuttings. Four selections had percentages of total mortality $\geq 70.0 \%$ (VEH-GRA-1037, VEH-GRA-10-38, JTV-JAD-10-42 and JTV-ESM-10-50), in addition to 'Okinawa' and 'Sharpe'.

Three selections stood out positively in percentage of live rooted cuttings in trial 1 (VHS-SEN-10-07, VHSSEN-10-10 and EM-SEN-10-25), with values equal to or greater than $75.0 \%$ (Table 2), statistically equal to three reference cultivars. Another ten selections stood out in trial 2, with percentages of live rooted cuttings greater than $37.5 \%$, and statistically higher in relation to three reference cultivars (Table 4). All 13 selections with the highest percentages of live rooted cuttings from both trials are also found in group of those with the highest percentages of rooted cuttings suitable to transplant (Tables 2 and 4).

For root number and root length, statistical differences were detected only in trial 1 (Table 3). Although with these significant differences, all treatments showed, in general, very satisfactory results, in both trials. In trial 1 (Table 3), root number per cutting varied between 5.43 (OS-GRA-
10-18) and 25.77 ('Sharpe'), with a length between $2.72 \mathrm{~cm}$ (OS-GRA-10 -18) and 8.80cm (VHS-SEN-10-09); in trial 2 (Table 5), root number per cutting ranged between 4.00 (ISD-GRA-10-53) and 18.84 ('Sharpe'), while root length ranged between $1.83 \mathrm{~cm}$ (JTV- ESM-10-50) and $8.12 \mathrm{~cm}$ (JTV-GRA-10-46).

For the percentages of cuttings with original leaves and sprouted cuttings in trial 1, there were statistical differences among treatments for both variables. For the first variable, VHS-SEN-10-07 (72.0\%), VHS-SEN-10-10 (67.5\%) and EM-SEN-10-25 (62.5\%) stood out, which were statistically equal to 'Capdeboscq' $(92.5 \%)$ and 'Sharpe' $(62.5 \%)$. The three reference cultivars had the highest percentage of sprouted cuttings, along with six other selections. However, considering both original leaves and the sprouting beginning, only a single selection (VHSSEN-10-07) stood out in trial 1, besides 'Capdeboscq' and 'Sharpe'. In trial 2, differences were only sprouted cuttings, with the majority (ten selections) being in group with the highest percentages, besides three cultivars.

\section{DISCUSSION}

Cuttings that died early without any adventitious roots (percentage of dead cuttings), were, in general, considered high, in both trials (Tables 2 and 4). Main factor responsible for this cutting mortality is early original leaf fall. Softwood

Table 3: Root quality, leaf persistence and sprouting of softwood cuttings from cultivars and clonal selections of Prunus spp. rootstocks under intermittent mist system (trial 1)

\begin{tabular}{|c|c|c|c|c|}
\hline Rootstock & $\begin{array}{l}\text { Root number } \\
\text { per cutting }\end{array}$ & $\begin{array}{l}\text { Root lenght } \\
\text { (cm) }\end{array}$ & $\begin{array}{c}\text { Cuttings with } \\
\text { original leaves }(\%)\end{array}$ & $\begin{array}{c}\text { Sprouted } \\
\text { cuttings }(\%)\end{array}$ \\
\hline VHS-SEN-10-07 & $8.92 \mathrm{c}$ & $8.03 \mathrm{a}$ & $72.00 \mathrm{a}$ & $32.50 \mathrm{a}$ \\
\hline VHS-SEN-10-08 & $8.78 \mathrm{c}$ & $5.56 \mathrm{~b}$ & $35.00 \mathrm{~b}$ & $7.50 \mathrm{~b}$ \\
\hline VHS-SEN-10-09 & $10.75 \mathrm{c}$ & $8.80 \mathrm{a}$ & $35.00 \mathrm{~b}$ & $37.50 \mathrm{a}$ \\
\hline VHS-SEN-10-10 & $9.52 \mathrm{c}$ & $6.13 \mathrm{a}$ & $67.50 \mathrm{a}$ & $7.50 \mathrm{~b}$ \\
\hline OS-JAD-10-12 & $5.52 \mathrm{c}$ & $3.42 \mathrm{~b}$ & $22.50 \mathrm{~b}$ & $17.50 \mathrm{~b}$ \\
\hline OS-JAD-10-13 & $9.40 \mathrm{c}$ & $4.67 \mathrm{~b}$ & $47.50 \mathrm{~b}$ & $0.00 \mathrm{~b}$ \\
\hline OS-GRA-10-16 & $15.90 \mathrm{~b}$ & $6.15 \mathrm{a}$ & $30.00 \mathrm{~b}$ & $35.00 \mathrm{a}$ \\
\hline OS-GRA-10-17 & $9.79 \mathrm{c}$ & $3.81 \mathrm{~b}$ & $25.00 \mathrm{~b}$ & $37.50 \mathrm{a}$ \\
\hline OS-GRA-10-18 & $5.43 \mathrm{c}$ & $2.72 \mathrm{~b}$ & $45.00 \mathrm{~b}$ & $2.50 \mathrm{~b}$ \\
\hline OS-GRA-10-20 & $13.45 \mathrm{c}$ & $4.65 \mathrm{~b}$ & $12.50 \mathrm{~b}$ & $5.00 \mathrm{~b}$ \\
\hline EM-PRE-10-21 & $11.59 \mathrm{c}$ & $7.57 \mathrm{a}$ & $40.00 \mathrm{~b}$ & $35.00 \mathrm{a}$ \\
\hline EM-SEN-10-25 & $12.96 \mathrm{c}$ & $6.75 \mathrm{a}$ & $62.50 \mathrm{a}$ & $10.00 \mathrm{~b}$ \\
\hline ENP-JAD-10-27 & $11.86 \mathrm{c}$ & $6.35 \mathrm{a}$ & $30.00 \mathrm{~b}$ & $35.00 \mathrm{a}$ \\
\hline VEH-GRA-10-31 & $6.00 \mathrm{c}$ & $3.99 \mathrm{~b}$ & $17.50 \mathrm{~b}$ & $0.00 \mathrm{~b}$ \\
\hline VEH-GRA-10-32 & $6.67 \mathrm{c}$ & $4.74 \mathrm{~b}$ & $12.50 \mathrm{~b}$ & $5.00 \mathrm{~b}$ \\
\hline Capdeboscq & $18.80 \mathrm{~b}$ & $8.57 \mathrm{a}$ & $92.50 \mathrm{a}$ & $25.00 \mathrm{a}$ \\
\hline Okinawa & $21.64 \mathrm{a}$ & $4.86 \mathrm{~b}$ & $37.50 \mathrm{~b}$ & $57.50 \mathrm{a}$ \\
\hline Sharpe & $25.77 \mathrm{a}$ & $6.94 \mathrm{a}$ & $62.50 \mathrm{a}$ & $65.00 \mathrm{a}$ \\
\hline $\mathrm{F}_{\text {rootstock }}$ & $6.13 *$ & $3.52 * *$ & $4.80 * *$ & $5.76^{* *}$ \\
\hline$\overline{\mathrm{CV}(\%)}$ & 38.36 & 33.15 & 37.56 & 58.83 \\
\hline
\end{tabular}

Means followed by different letters in the column differ from each other by the Scott-knott test. * Significant at 5\% error probability; ** significant at $1 \%$ error probability. 
cuttings without their original leaves do not perform photosynthesis and do not produce cofactors essential to rooting and, with the high summer air temperatures and without having started the rhizogenesis, they die early (Machida et al., 1977; Hartmann et al., 2002; Thomas \& Schiefelbein, 2004; Santoro et al., 2010; Tombesi et al. 2015; Sanchez et al., 2020). Leaves are essential for softwood cuttings of peach and several other species (Hartmann et al., 2002; Thomas \& Schiefelbein, 2004; Santoro et al., 2010; Mayer et al., 2014b; Mayer et al., 2015a; Tombesi et al. 2015; Mayer et al., 2018). There are several factors that can contribute to the early original leaf fall on cuttings under intermittent mist system, such as the deficient nutrition of mother tree, inappropriate shoots for cutting preparation (date, type, age, size, diameter, health, etc...), endogenous hormonal balance favorable to leaf senescence, genetics, leaf and petiole morphology, water stress (from the air and/or substrate), inadequate regulation of mist system, thermal stress (especially air temperature differences between day and night), fungal diseases, and inappropriate containers and/ or substrates (Hartmann et al., 2002; Osterc et al., 2009; Osterc \& Štampar, 2011; Neèas \& Krška, 2013; Ruter, 2015; Fragoso et al., 2015; Mayer et al., 2015a; Mayer et al., 2020). Some of these factors usually occur simultaneously, to a greater or lesser degree, and, in most cases, it is difficult to identify a single factor as the causal agent of early original leaf fall. In the present research, cuttings were not previously disinfected with fungicides. Fluctuations in air temperature and air relative humidity in both trials (Table 1), especially between day and night, may also have contributed to leaf water stress and for the substrate.

The percentage of dead rooted cuttings is another undesirable variable and reveals that adventitious root formation process has started, however, normally due to the water excess in substrate, there is no proper aeration at cutting base, which end up dying. In this respect, the environmental differences between day and night (especially air temperature and air relative humidity) are factors that vary significantly (Table 1). So, that is difficult to adjust mist schedule to maintain leaves adequately moistened during the day (with temperatures greater than $40^{\circ} \mathrm{C}$ ), without causing the substrate to soak during the night, when temperatures fall around $15^{\circ} \mathrm{C}$. Additionally, fine vermiculite + perlite mixture $(1: 1)$ used as a substrate, combined with plastic boxes characteristics, probably were not sufficient for perfect drainage, and had a similar performance to pure fine vermiculite (Mayer et al., 2020).

According to Mattson \& Fulcher (2015), the ability of a substrate to retain water and air is dependent on particles

Table 4: Rooting response of softwood cuttings from cultivars and clonal selections of Prunus spp. rootstocks under intermittent mist system (trial 2)

\begin{tabular}{|c|c|c|c|c|c|}
\hline \multirow{2}{*}{ Rootstock } & $\begin{array}{c}\text { Dead } \\
\text { cuttings }\end{array}$ & $\begin{array}{c}\text { Dead } \\
\text { rooted cuttings }\end{array}$ & $\begin{array}{c}\text { Live } \\
\text { rooted cuttings }\end{array}$ & $\begin{array}{c}\text { Suitable } \\
\text { rooted cuttings }\end{array}$ & $\begin{array}{c}\text { Unsuitable } \\
\text { rooted cuttings }\end{array}$ \\
\hline & \multicolumn{5}{|c|}{$(\%)$} \\
\hline VEH-GRA-10-33 & $25.00 \mathrm{a}$ & $27.50 \mathrm{a}$ & $47.50 \mathrm{a}$ & $23.81 \mathrm{a}$ & $76.19 \mathrm{a}$ \\
\hline VEH-GRA-10-36 & $25.00 \mathrm{a}$ & $17.50 \mathrm{a}$ & $57.50 \mathrm{a}$ & $36.61 \mathrm{a}$ & $63.39 \mathrm{a}$ \\
\hline VEH-GRA-10-37 & $47.50 \mathrm{a}$ & $27.50 \mathrm{a}$ & $25.00 \mathrm{~b}$ & $25.00 \mathrm{a}$ & $75.00 \mathrm{a}$ \\
\hline VEH-GRA-10-38 & $55.00 \mathrm{a}$ & $25.00 \mathrm{a}$ & $20.00 \mathrm{~b}$ & $39.58 \mathrm{a}$ & $60.42 \mathrm{a}$ \\
\hline VEH-GRA-10-39 & $25.00 \mathrm{a}$ & $12.50 \mathrm{a}$ & $62.50 \mathrm{a}$ & $28.47 \mathrm{a}$ & $71.53 \mathrm{a}$ \\
\hline JTV-JAD-10-41 & $32.50 \mathrm{a}$ & $32.50 \mathrm{a}$ & $25.00 \mathrm{~b}$ & $50.00 \mathrm{a}$ & $50.00 \mathrm{a}$ \\
\hline JTV-JAD-10-42 & $47.50 \mathrm{a}$ & $22.50 \mathrm{a}$ & $30.00 \mathrm{~b}$ & $27.08 \mathrm{a}$ & $72.92 \mathrm{a}$ \\
\hline JTV-JAD-10-43 & $42.50 \mathrm{a}$ & $12.50 \mathrm{a}$ & $45.00 \mathrm{a}$ & $41.67 \mathrm{a}$ & $58.33 \mathrm{a}$ \\
\hline JTV-JAD-10-44 & $27.50 \mathrm{a}$ & $27.50 \mathrm{a}$ & $45.00 \mathrm{a}$ & $23.75 \mathrm{a}$ & $76.25 \mathrm{a}$ \\
\hline JTV-GRA-10-46 & $20.00 \mathrm{a}$ & $17.50 \mathrm{a}$ & $55.00 \mathrm{a}$ & $43.16 \mathrm{a}$ & $56.85 \mathrm{a}$ \\
\hline JTV-GRA-10-47 & $17.50 \mathrm{a}$ & $25.00 \mathrm{a}$ & $57.50 \mathrm{a}$ & $25.83 \mathrm{a}$ & $74.17 \mathrm{a}$ \\
\hline JTV-ESM-10-50 & $32.50 \mathrm{a}$ & $37.50 \mathrm{a}$ & $30.00 \mathrm{~b}$ & $50.00 \mathrm{a}$ & $25.00 \mathrm{~b}$ \\
\hline ISD-GRA-10-53 & $35.00 \mathrm{a}$ & $17.50 \mathrm{a}$ & $45.00 \mathrm{a}$ & $15.00 \mathrm{a}$ & $85.00 \mathrm{a}$ \\
\hline ISD-ELD-10-55 & $20.00 \mathrm{a}$ & $27.50 \mathrm{a}$ & $55.00 \mathrm{a}$ & $58.45 \mathrm{a}$ & $41.55 \mathrm{a}$ \\
\hline VS-ELD-10-59 & $42.50 \mathrm{a}$ & $17.50 \mathrm{a}$ & $37.50 \mathrm{a}$ & $16.67 \mathrm{a}$ & $83.34 \mathrm{a}$ \\
\hline Capdeboscq & $32.50 \mathrm{a}$ & $32.50 \mathrm{a}$ & $35.00 \mathrm{~b}$ & $42.14 \mathrm{a}$ & $57.86 \mathrm{a}$ \\
\hline Okinawa & $52.50 \mathrm{a}$ & $25.00 \mathrm{a}$ & $7.50 \mathrm{~b}$ & $50.00 \mathrm{a}$ & $0.00 \mathrm{~b}$ \\
\hline Sharpe & $5.00 \mathrm{a}$ & $65.00 \mathrm{a}$ & $30.00 \mathrm{~b}$ & 66.67 a & $8.33 \mathrm{~b}$ \\
\hline $\mathrm{F}_{\text {rootstock }}$ & $1.83 *$ & $1.51^{\mathrm{NS}}$ & $2.31 *$ & $0.72^{\mathrm{NS}}$ & $3.34 * *$ \\
\hline $\mathrm{CV}(\%)$ & 45.57 & 51.12 & 38.54 & 79.21 & 45.85 \\
\hline
\end{tabular}

Means followed by different letters in the column differ from each other by the Scott-knott test. ${ }^{\text {NS }}$ Not significant; * significant at $5 \%$ error probability; ** significant at $1 \%$ error probability. 
size. A finer textured substrate, that is, with smaller particles, tends to retain more water in relation to a coarse textured substrate, increasing saturation zone at container bottom and reaching cuttings base. Therefore, alternative substrates should be studied, with a thicker texture and capable of allowing better aeration at the cutting base, as a way of reducing cutting mortality after rhizogenesis.

The percentages of live rooted cuttings in both trials (Tables 2 and 4) were considered satisfactory. The percentage of live rooted cuttings is the key in cutting propagation trials (Hartmann et al., 2002; Mayer et al., 2018; Mayer et al., 2020). The highest values observed in 10 selections (trial 2, Table 4) and statistical equality of three selections (trial 1, Table 2), in relation to the reference cultivars, reveals that selected clones also present satisfactory rooting ability, besides potentially tolerant to the PTSL syndrome. According to the literature review made by Neèas \& Krška (2013), a rooting yields of around $30 \%$ can be considered as the limit for difficult to propagate genotypes and $50 \%$ is the limit of successful propagation. The same authors mention that over $60 \%$ success can be considered as economically effective propagation and over $75 \%$ success is highly effective propagation. Thus, considering the 30 rootstock selections tested in the present research and $50 \%$ of live rooted cuttings as a limit, seven and five selections (trials 1 and 2, respectively) stood out, but VHS-SEN-1007, VHS-SEN-10-10 and EM-SEN-10-25 can be sorted as highly effective propagation genotypes.

Another important variable is the percentage of rooted cuttings suitable for transplanting, because in addition to being indicative of root quality, it also translates the amount of usable rooted cuttings for the subsequent phase (transplanting and acclimatization). In both trials (Tables 2 and 4), all selections tested were statistically similar to the three reference cultivars, another important characteristic verified in selected clones. The quality of adventitious root system is also expressed by root number and root length. Although statistical differences were detected in both variables in trial 1 , and statistical equality in trial 2 , results of these variables, in general, were considered quite satisfactory. The number of primary roots that tree will have in the orchard is defined during propagation time under mist system (normally 60 days) (Mayer et al., 2014b; Mayer et al., 2018; Mayer et al., 2020). Consequently, root number and root distribution around cutting will influence the performance of mature tree. With a vigorous and wide root system, there will be greater possibilities for tree adaptation to gravel soils and water deficit, common situations in peach area in Pelotas-RS where PTSL syndrome occurs (Mayer \& Ueno, 2012; Mayer et al., 2015b; Alba et al., 2019; Mayer \& Ueno, 2021).

Table 5: Root quality, leaf persistence and sprouting of softwood cuttings from cultivars and clonal selections of Prunus spp. rootstocks under intermittent mist system (trial 2)

\begin{tabular}{|c|c|c|c|c|}
\hline Rootstock & $\begin{array}{l}\text { Root number } \\
\text { per cutting }\end{array}$ & $\begin{array}{l}\text { Root lenght } \\
\quad(\mathrm{cm})\end{array}$ & $\begin{array}{c}\text { Cuttings with } \\
\text { original leaves }(\%)\end{array}$ & $\begin{array}{c}\text { Sprouted } \\
\text { cuttings }(\%)\end{array}$ \\
\hline VEH-GRA-10-33 & $13.54 \mathrm{a}$ & $6.31 \mathrm{a}$ & $25.00 \mathrm{a}$ & $57.50 \mathrm{a}$ \\
\hline VEH-GRA-10-36 & $9.62 \mathrm{a}$ & $6.99 \mathrm{a}$ & $45.00 \mathrm{a}$ & $30.00 \mathrm{~b}$ \\
\hline VEH-GRA-10-37 & $7.44 \mathrm{a}$ & $5.65 \mathrm{a}$ & $5.00 \mathrm{a}$ & $40.00 \mathrm{a}$ \\
\hline VEH-GRA-10-38 & $5.92 \mathrm{a}$ & $3.05 \mathrm{a}$ & $10.00 \mathrm{a}$ & $5.00 \mathrm{c}$ \\
\hline VEH-GRA-10-39 & $11.12 \mathrm{a}$ & $7.73 \mathrm{a}$ & $45.00 \mathrm{a}$ & $45.00 \mathrm{a}$ \\
\hline JTV-JAD-10-41 & $17.98 \mathrm{a}$ & $6.97 \mathrm{a}$ & $15.00 \mathrm{a}$ & $50.00 \mathrm{a}$ \\
\hline JTV-JAD-10-42 & $7.42 \mathrm{a}$ & $5.85 \mathrm{a}$ & $25.00 \mathrm{a}$ & $27.50 \mathrm{~b}$ \\
\hline JTV-JAD-10-43 & $9.90 \mathrm{a}$ & $6.63 \mathrm{a}$ & $27.50 \mathrm{a}$ & $42.50 \mathrm{a}$ \\
\hline JTV-JAD-10-44 & $15.63 \mathrm{a}$ & $5.98 \mathrm{a}$ & $22.50 \mathrm{a}$ & $47.50 \mathrm{a}$ \\
\hline JTV-GRA-10-46 & $6.82 \mathrm{a}$ & $8.12 \mathrm{a}$ & $50.00 \mathrm{a}$ & $52.50 \mathrm{a}$ \\
\hline JTV-GRA-10-47 & $8.50 \mathrm{a}$ & $5.13 \mathrm{a}$ & $37.50 \mathrm{a}$ & $52.50 \mathrm{a}$ \\
\hline JTV-ESM-10-50 & $7.25 \mathrm{a}$ & $1.83 \mathrm{a}$ & $27.50 \mathrm{a}$ & $22.50 \mathrm{~b}$ \\
\hline ISD-GRA-10-53 & $4.00 \mathrm{a}$ & $5.29 \mathrm{a}$ & $30.00 \mathrm{a}$ & $75.00 \mathrm{a}$ \\
\hline ISD-ELD-10-55 & $16.91 \mathrm{a}$ & $7.67 \mathrm{a}$ & $42.50 \mathrm{a}$ & $55.00 \mathrm{a}$ \\
\hline VS-ELD-10-59 & $8.54 \mathrm{a}$ & $7.54 \mathrm{a}$ & $37.50 \mathrm{a}$ & $20.00 \mathrm{~b}$ \\
\hline Capdeboscq & $6.45 \mathrm{a}$ & $6.90 \mathrm{a}$ & $32.50 \mathrm{a}$ & $37.50 \mathrm{a}$ \\
\hline Okinawa & $7.75 \mathrm{a}$ & $3.45 \mathrm{a}$ & $15.00 \mathrm{a}$ & $50.00 \mathrm{a}$ \\
\hline Sharpe & $18.84 \mathrm{a}$ & $7.88 \mathrm{a}$ & $40.00 \mathrm{a}$ & $42.50 \mathrm{a}$ \\
\hline $\mathrm{F}_{\text {rootstock }}$ & $1.36^{\mathrm{NS}}$ & $1.68^{\mathrm{NS}}$ & $1.77^{\mathrm{NS}}$ & $9.92 * *$ \\
\hline$\overline{\mathrm{CV}(\%)}$ & 75.09 & 45.17 & 47.14 & 30.79 \\
\hline
\end{tabular}

Means followed by different letters in the column differ from each other by the Scott-knott test. ${ }^{\text {NS }}$ Not significant; ${ }^{* *}$ significant at $1 \%$ error probability.

Rev. Ceres, Viçosa, v. 68, n.3, p. 230-238, may/jun, 2021 
As already discussed, permanence of original leaves to the cutting is essential for photosynthesis and production of cofactors for rhizogenesis in several species, including peach (Machida et al., 1977; Hartmann et al., 2002; Thomas \& Schiefelbein, 2004; Santoro et al., 2010; Mayer et al., 2014b; Mayer et al., 2015a; Tombesi et al. 2015; Mayer et al., 2018; Sanchez et al., 2020). According to results (Tables 3 and 5), most selections (twelve) in trial 1 and all selections in trial 2 presented percentages $\leq 50.0 \%$ of cutting with original leaves. However, this low data was compensated, at least in part, by the sprouting of cuttings under intermittent mist system (Tables 3 and 5). Only two selections (OS-JAD-10-13 and VEH-GRA-10-31) did not sprout during time under intermittent mist, however, due to the original leaf retention (47.5 and $17.5 \%$, respectively), it was possible to obtain rooting (50.0 and $17.5 \%$, respectively). The photosynthesis and phytohormones production is continuous, if cuttings retain their original leaves and/or new sprouts emerge. Growing tips, leaves and buds are sites indole-acetic acid synthesis, which contributes to adventitious root formation (Hartmann et al., 2002; Fragoso et al., 2015; Mayer et al., 2018). Softwood cuttings of 'Lovell' or semihardwood cuttings of 'Guardian ${ }^{\circledR}$ ' rootstocks (P. persica) did not sprout at rooting phase under a mist system, but still excellent rooting percentages $(>85 \%$ ) can be obtained (Mayer et al., 2015a). In peach rootstock selections, sprouting percentages of softwood cuttings were usually higher than percentages of cuttings with original leaves, so satisfactory rooting could be obtained (Mayer et al., 2018; Mayer et al., 2020).

Air temperature and its amplitude is another factor that affects rooting of cuttings (Hartmann et al., 2002; Ruter, 2015). The ideal range temperature for rooting cuttings will depend on specie, cutting type, season and rooting facilities (Ruter, 2015). In general, air temperatures between $15^{\circ} \mathrm{C}$ and $27^{\circ} \mathrm{C}$ is an ideal range for temperate fruit species (Hartmann et al., 2002). In both trials, it was observed that temperatures $>27^{\circ} \mathrm{C}$ occurred between 9:00 am and 6:30 pm, or that is, during practically the whole daytime. So, air temperatures $>27^{\circ} \mathrm{C}$ occurred during a significant part of total rooting time for both trials (Table 1), as well as the thermal amplitude in $24 \mathrm{~h}$ was too high, which may have caused stress on cuttings and reduced rooting percentages and root quality. Therefore, the environmental conditions registered in both trials were quite similar, suggesting need some changes in the facilities to reduce maximum air temperatures, in order to promote a longer period of thermal comfort.

\section{CONCLUSIONS}

Softwood cuttings under intermittent mist system are a feasible way to propagate peach rootstock selections of
2010/2011 PTSL selection cycle. Root quality was satisfactory in most of studied selections, with high percentages of cuttings suitable for transplanting and excellent root number and root length. OS-GRA-10-17, VEH-GRA-10-31, VEH-GRA-10-32, VEH-GRA-10-37 and VEH-GRA-10-38 selections had the highest mortality rates and the lowest percentages of live rooted cuttings. Several selections have similar or superior propagation potential in relation to three reference cultivars. The ease of vegetative propagation and root quality must be taken into account, in the search for promising rootstock.

\section{ACKNOWLEDGEMENTS, FINANCIAL SUPPORT AND FULL DISCLOSURE}

This research was supported by Empresa Brasileira de Pesquisa Agropecuária (Embrapa) and Conselho Nacional de Desenvolvimento Científico e Tecnológico (CNPq). There is no conflict of interest in conducting and publishing this paper.

\section{REFERENCES}

Alba JMF, Mayer NA, Ueno B \& Costa FA (2019) Fatores ambientais envolvidos na morte precoce do pessegueiro na região de Pelotas, RS. Pelotas, Embrapa Clima Temperado. 10p. (Technical Bulletin, 368).

Anderson NO, Hoover E, Kostick SA, Tepe E \& Tillman J (2016) Cutting type and time-of-year affect rooting ability of hardy Minnesota Prunus species. Journal of the American Pomological Society 70: 114-123.

Beckman TG, Chaparro JX \& Sherman WB (2008) 'Sharpe', a clonal plum rootstock for peach. HortScience, 43:2236-2337.

Beckman TG, Chaparro JX \& Sherman WB (2012) 'MP-29', a clonal interspecific hybrid rootstock for peach. HortScience, 47:128-131.

Brittain JA \& Miller Jr RW (1978) Managing peach tree short life in the Southeast. Washington, Agricultural Extension Services of Georgia, Alabama, North Carolina, South Carolina and the United States Department of Agriculture cooperating. 19p. (Circular, 585).

Campos AD, Carneiro RMDG, Gomes CB \& Mayer NA (2014) Morte precoce de plantas. In: Raseira MCB, Pereira JFM\& Carvalho FLC (Eds) Pessegueiro. Brasília, Embrapa. p.509-530.

Canteri MG, Althaus RA, Virgens Filho JS, Giglioti EA \& Godoy CV (2001) SASM - Agri: Sistema para análise e separação de médias em experimentos agrícolas pelos métodos ScottKnott, Tukey e Duncan. Revista Brasileira de Agrocomputação, 1:18-24.

Fragoso RO, Witt NGP, Obrzut VV, Valério S, Zuffellato-Ribas KC \& Stuepp CA (2015) Maintenance of leaves and indolebutyric acid in rooting of juvenile japanese flowering cherry cuttings. Revista Brasileira de Ciências Agrárias, 10:97-101.

Hartmann HT, Kester DE, Davies Jr FT \&G eneve RL (2002) Plant propagation: principles and practices. $7^{\text {the }}$ d. New Jersey, Prentice Hall. 880p.

Machida H, Ooishi A, Hosoi T, Komatsu H \& Kamota F (1977) Studies on photosynthesis in cuttings during propagation I. Changes in the rate of apparent photosynthesis in the cuttings of several plants after planting. Journal Japanese Society Horticultural Science, 46: 274-282. 
Mattson NS \& Fulcher A (2015) Substrates and containers for seed and cutting propagation and transplanting. In: Beyl CA \& Trigiano RN (Eds) Plant propagation concepts and laboratory exercises. Boca Raton, Taylor \& Francis Group. p.127-144.

Mayer NA, Ueno B \& Antunes LEC (2009) Seleção e clonagem de porta-enxertos tolerantes à morte-precoce do pessegueiro. Pelotas, Embrapa Clima Temperado. 16p. (Technical Bulletin, 209).

Mayer NA \& Ueno B (2012) A morte-precoce do pessegueiro e suas relações com porta-enxertos. Pelotas, Embrapa Clima Temperado. 42p. (Technical Bulletin, 359).

Mayer NA, Bianchi VJ \& Castro LAS (2014a) Porta-enxertos. In: Raseira MCB, Pereira JFM \& Carvalho FLC (Eds) Pessegueiro. Brasília, Embrapa. p.173-223.

Mayer NA, Picolotto L, Bastos PV, Ueno B \& Antunes LEC (2014b) Estaquia herbácea de porta-enxertos de pessegueiro no final do verão. Semina: Ciências Agrárias, 35:1761-1772.

Mayer NA \& Ueno B (2015) 'Sharpe': porta-enxerto para pessegueiro introduzido no Brasil pela Embrapa Clima Temperado. Pelotas, Embrapa Clima Temperado. 27p. (Technical Bulletin, 392).

Mayer NA, Reighard GL \& Bridges W (2015a) Peach rootstock propagation under intermittent mist system. Acta Horticulturae, 1084:53-62.

Mayer NA, Ueno B, Silva VAL, Valgas RA \& Silveira CAP (2015b) A morte precoce do pessegueiro associada à fertilidade do solo. Revista Brasileira de Fruticultura, 37:773-787.

Mayer NA, Ueno B \& Neves TR (2018) Propagação vegetativa de seleções de porta-enxerto potencialmente tolerantes à morte-precoce do pessegueiro. Revista de Ciências Agroveterinárias, 17:300-308.

Mayer NA, Ueno B, Rickes TB \& Resende, MVLA (2020) Cloning of rootstock selections and Prunus spp. cultivars by softwood cuttings. Scientia Horticulturae, 273:109609.

Mayer NA \& Ueno B (2021) A morte precoce do pessegueiro no estado do Rio Grande do Sul, Brasil. Agrociencia Uruguay, 25: article 395.

Menegatti RD, Souza G \& Bianchi VJ (2019) Estimating genetic divergence between peach rootstock cultivars using multivariate techniques based on characteristics associated with seeds. Genetics and Molecular Research, 18:1-10.

Neèas T \& Krška B (2013) Propagation of different stone fruit rootstocks using softwood and hardwood cuttings. Acta Horticulturae, 985:127-137.

Okie WR, Beckman TG, Nyczepir AP, Reighard GL, Newall WC \& Zehr EI (1994) BY520-9, A peach rootstock for the Southeastern United States that increases scion longevity. HortScience, 29:705-706.
Okie WR \& Nyczepir AP (2004) Effect of winter root-zone temperature on root regeneration of peach rootstocks. HortScience, 39:1607-1610.

Oliveira JAA, Bruckner CH, Silva DFP, Santos CEM, Penso GA \& Aquino CF (2018) Estimation of genetic parameters and selection for rooting capacity in peach. Crop Breeding and Applied Biotechnology, 18:320-324.

Osterc G, Stefancic M \& Stampar F (2009) Juvenile stock plant material enhances root development through higher endogenous auxin level. Acta Physiologica Plantarum, 31:899-903.

Osterc G \& Štampar F (2011) Differences in endo/exogenous auxin profile in cuttings of different physiological ages. Journal of Plant Physiology, 168:2088-2092.

Reighard GL \& Loreti F (2008) Rootstock development. In: Layne DR \& Bassi D (Eds) The peach: botany, production and uses. Cambridge, CABI. p.193-220.

Ruter JM (2015) Cloning plants by rooting stem cuttings. In: Beyl CA \& Trigiano RN (Eds) Plant propagation concepts and laboratory exercises. Boca Raton, Taylor \& Francis Group. p.217229.

Sanchez O, Burnett SE \& Peterson BJ (2020) Environment, photosynthesis, and adventitious rooting of manchurian lilac cuttings propagated in overhead mist, submist, and combination systems. Hortscience, 55:78-82.

Santoro PH, Mikami AY, Souza SGH \& Roberto SR (2010) Influência de folhas e lesões na base de estacas herbáceas no enraizamento de goiabeira da seleção 8501-9. Semina: Ciências Agrárias, 31:289-294.

Thomas P \& Schiefelbein JW (2004) Roles of leaf in regulation of root and shoot growth from single node softwood cuttings of grape (Vitis vinifera). Annals Aplied Biology, 144:27-37.

Tombesi S, Palliotti A, Poni S \& Farinelli D (2015) Influence of light and shoot development stage on leaf photosynthesis and carbohydrate status during the adventitious root formation in cuttings of Corylus avellana L. Frontiers in Plant Science, 6:113 .

Ueno B, Mayer NA, Gomes CB \& Campos AD (2019) Morte precoce. In: Mayer NA,Franzon RC \& Raseira MCB (Eds) Pêssego, nectarina e ameixa: o produtor pergunta, a Embrapa responde. Brasília,Embrapa. p.207-222.

Warschefsky EJ, Klein LL, Frank MH, Chitwood DH, Londo JP, Wettberg EJB \& Miller AJ (2016) Rootstocks: diversity, domestication, and impacts on shoot phenotypes. Trends in Plant Science, 21:418-437. 